\title{
Pengaruh Pemberian Seduhan Teh Hijau (Camellia Sinensis) Terhadap Aktivitas Superoksida Dismutase (SOD)
}

\author{
Ma'rifat Istiqa M ukty ${ }^{1 *}$,Bambang Wirjatmadi ${ }^{2}$, Bambang Purwanto ${ }^{3}$ \\ Mahasiswa M agister Fakultas Kesehatan M asyarakat Universitas Airlangga ${ }^{1}$ \\ Departemen Gizi Kesehatan M asyarakat Universitas Airlangga ${ }^{2,3}$ \\ Fakultas Kedokteran Universitas Airlangga \\ JI. Dr. Ir. H. Soekarno, Mulyorejo, Kota Surabaya, jawa Timur, 60115 \\ *e-mail: istiqamukty.im@gmail.com
}

\begin{abstract}
Abstrak
Stres oksidatif merupakan suatu kondisi dimana terjadi ketidakseimbangan antara oksidan dan antioksidan didalam tubuh sehingga dapat memicu adanya stres psikologis. Stres oksidatif dapat dikurangi dengan mengkonsumsi zat antioksidan eksogen (antioksidan dari luar), yang mana teh hijau dianggap mampu menurunkan stres oksidatif. Tujuan penelitian ini adalah untuk menguji pengaruh pemberian seduhan teh hijau terhadap aktivitas SOD pada tikus putih jantan Strain Wistar yang dipapar stres psikologis. Rancang bangun yang digunakan pada penelitian ini adalah Randomized Post Test Only Group Design. Terdapat 5 kelompok tikus, 2 adalah kelompok kontrol normal dan kelompok kontrol stres, serta 3 kelompok perlakuan. Sebelumnya tikus diberikan stres psikologis 1 × 24 jam berupa gangguan pola tidur jaga, sehingga didapatkan kondisi hewan coba yang mengalami stres oksidatif, kemudian dilakukan pemberian seduhan teh hijau pada kelompok perlakuan dengan dosis tunggal 3,6 ml/ekor pada jam ke-1 pada kelompok perlakuan 1, jam ke-6 pada kelompok perlakuan 2 dan jam ke24 pada kelompok perlakuan 3. Analisis statistik menggunakan uji M anova. Hasil Berdasarkan analisis statistik menunjukkan bahwa terdapat perbedaan aktivitas SOD yang meningkat pada jam ke-1, kembali meningkat pada jam ke-6 dan meningkat maksimal pada jam ke-24 setelah pemberian teh hijau. Dosis tunggal seduhan teh hijau pada hewan coba yang mengalami stres oksidatif terbukti dapat menetralisir stres oksidatif pada jam ke-1 setelah pemberian teh hijau dan aktivitas antioksidannya masih bertahan sampai 24 jam.
\end{abstract}

Kata kunci: Stres Oksidatif, Teh Hijau, SOD

\section{Effect Of Green Tea (Camellia Sinensis) Against Supeoxyde Dismutase (SOD) Activity}

\begin{abstract}
Oxidative stress can be triggered by exposure to psychological stress. Oxidative stress can be reduced by the consumption of exogenous antioxidants, green tea is thought to be able to reduce oxidative stress. The purpose of this study was to examine the effect of green tea sediments on blood glucose, MDA and SOD activity on Wistar Strain white rats exposed to psychological stress. The design used in this research is Randomized Post Test Only Group Design. There were 5 groups of mice, 2 were normal control group and stress control group, and 3 treatment groups. Previously, rats were given psychological stress $1 \times 24$ hours in the form of disturbance of sleeping guard pattern, so that got the condition of experimental
\end{abstract}


Pengaruh Pemberian Seduhan Teh Hijau (Camellia Sinensis) Terhadap Aktivitas Superoksida... Ma'rifat Istiqa Mukty, Bambang Wirjatmadi, Bambang Purwanto

animals that experienced oxidative stress, then done the giving of green tea in treatment group with single dose 3,6 $\mathrm{ml} /$ tai at hour 1 in group treatment 1, 6th hour in treatment group 2 and hour 24 in treatment group 3. Statistical analysis using Manova test. Results Based on statistical analysis showed that there was a difference of SOD activity increased at the 1st hour, again increased at 6 th hour and increased maximum at 24 hours after the green tea. A single dose of green tea in experimental animals experiencing oxidative stress has been shown to neutralize oxidative stress at $1 \mathrm{am}$ after green tea and antioxidant activity persist for up to 24 hours.

Keyword: Oxidative stress, green tea, SOD

\section{PENDAHULUAN}

Stres psikologis seringkali dihadapi oleh orang dengan gangguan ritme tubuh, salah satunya adalah dengan mengalami fase tidur jaga terbalik (Maramis, 2009). Pergeseran zaman yang menyebabkan tingginya tekanan dan beban hidup terhadap kondisi sosial, ekonomi, dan lingkungan yang tidak menguntungkan dapat meningkatkan risiko terhadap stres psikologis. Pencegahan sangat penting dilakukan guna menekan angka kesakitan dan kematian. Stres oksidatif dapat dikurangi dengan peningkatan produksi antioksidan yang bisa diperoleh dari luar tubuh untuk membantu efektivitas kerja antioksidan dari dalam tubuh (endogen). Salah satu bahan yang bisa memberi efek menekan proses stres oksidatif adalah teh hijau (Camellia Sinensis) dimana teh hijau dianggap memiliki kemampuan dalam menurunkan kadar glukosa darah dan bersifat antioksidan dalam tubuh sehingga mampu menurunkan kadar MDA dan meningkatkan aktivitas SOD. Polyphenols pada teh hijau didalamnya mengandung senyawa flavonoid yang paling mendominasi diantara komponen teh hijau lainnya (sekitar $75 \%$ ) dari total polyphenols pada teh hijau (Shabri dan Rohdiana, 2016). Flavonoid yang paling utama adalah catechin (sekitar 20-30\%) dari seluruh berat kering daun (Anjarsari, 2016), dimana (Epigallocatechin gallate) EGCG merupakan senyawa yang paling aktif dalam komponen catechin dibandingkan dengan senyawa lainnya.

\section{BAHAN DAN METODE}

Rancang bangun yang digunakan pada penelitian ini adalah Randomized Post Test Only Group Design. Penelitian eksperimental laboratories ini menggunakan 25 ekor tikus putih jantan Strain Wistar (Rattus Norvegicus) sebagai hewan coba dan dikelompokkan menjadi 5 kelompok. Kelompok kontrol normal (K1), kelompok kontrol stres (K2) dan kelompok perlakuan P1 untuk pemeriksaan 1 jam setelah pemberian seduhan teh hijau, P2 pemeriksaan 6 jam setelah pemberian seduhan teh hijau dan P3 pemeriksaan 24 
ISSN 1978-2071 (Print); ISSN 2580-5967 (Online) Jurnal IImiah Kedokteran Wijaya Kusuma 7(2) : 158-164, September 2018

jam setelah pemberian seduhan teh hijau. Sebelumnya tikus diberikan stres psikologis $1 \times 24$ jam berupa gangguan pola tidur jaga, sehingga dapat terjadi stres oksidatif. Pemberian seduhan teh hijau sesaat setelah perlakuan stres psikologis dengan dosis tunggal $3,6 \mathrm{ml}$ tiap ekor tikus. Perlakuan stres psikologis diberikan dengan gangguan pola tidur-jaga terbalik, dilakukan dengan tahapan sebagai berikut: a). Perlakuan ini diberikan pada kelompok K2, P1, P2, dan P3. Kelompok K1 tidak diberi perlakuan stres psikologis. b). Dilakukan pada hari ke-8, selama 1 × 24 jam. c). Pada siang hari menempatkan 1 kelompok tikus pada satu kandang kaca tertutup, untuk membangunkan tikus yang sedang tidur diberikan goncangan, kemudian diberikan sinar lampu yang terang pada waktu siang hari dan pemadaman lampu, kamar gelap pada malam harinya. d). Pemberian makanan dan minuman pada siang hari. e). Untuk menghindari perkelahian antar tikus dalam 1 kelompok, maka diberikan sekat untuk masing-masing ekor tikus dari bahan yang tembus pandang, sehingga tikus tetap bisa mengamati tikus yang lainnya. Analisis statistik menggunakan uji Manova (Multivariate Analyses of Variance) untuk melihat perbedaan aktivitas SOD di masingmasing kelompok. Izin etik penelitian ini telah diterima dan bukti dengan sertifikat persetujuan etik dari Forum Penelitian Kesehatan Etik Fakultas Kesehatan Masyarakat Universitas Airlangga.

HASIL

Rata-rata kadar SOD yang paling rendah adalah kelompok kontrol stres (K2) yaitu sebesar 89,63 $\pm 1,014 \mathrm{U} / \mathrm{mL}$, selanjutnya kadar SOD lebih tinggi didapatkan pada kelompok kontrol normal (K1) sebesar 91,31 $\pm 1,030 \mathrm{U} / \mathrm{mL}$. rata-rata aktivitas SOD mulai meningkat pada kelompok P1 dan P2, dan semakin meningkat pada kelompok P3.

Tabel 1. rata-rata superokside dismutase pada kelompok kontrol dan kelompok perlakuan pada hewan coba tikus putih jantan strain wistar

\begin{tabular}{ccc}
\hline Kelompok & $\mathbf{n}$ & SOD (U/ mL) \\
\cline { 3 - 3 } & & Mean $\mathbf{\text { SD }}$ \\
\hline K1 & 5 & $91,31 \pm 1,030$ \\
K2 & 5 & $89,63 \pm 1,014$ \\
P1 & 5 & $92,92 \pm 1,229$ \\
P2 & 5 & $93,33 \pm 1,229$ \\
P3 & 5 & $94,22 \pm 1,097$ \\
\hline
\end{tabular}

Perbedaan rata-rata aktivfitas SOD di setiap kelompok dapat ditunjukkan pada Gambar 1. di bawah ini. 
Pengaruh Pemberian Seduhan Teh Hijau (Camellia Sinensis) Terhadap Aktivitas Superoksida... Ma'rifat Istiqa Mukty, Bambang Wirjatmadi, Bambang Purwanto

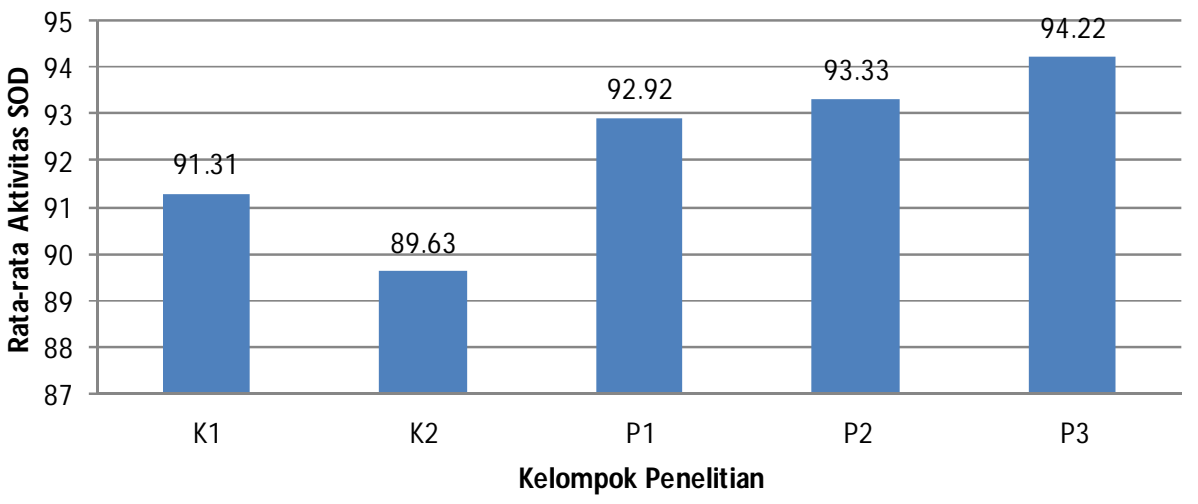

Gambar 1. Grafik rata-rata aktivitas SOD (u/ml) pada seluruh kelompok hewan coba.

Berdasarkan uji Manova, pada seluruh kelompok hewan coba terhadap SOD diperoleh $p=0,000 \varangle 0,05$ sehingga dapat dikatakan bahwa terdapat pengaruh yang bermakna setelah pemberian seduhan teh hijau pada seluruh kelompok hewan coba terhadap aktivitas SOD. Kemudian, untuk mengetahui kelompok yang berbeda secara signifikan berdasarkan p. value dapat dilihat pada Tabel 2 berikut.

Tabel 2. Nilai $p$ value uji Isd (SOD), tahun 2018

\begin{tabular}{cccccc}
\hline Kelompok & K1 & K2 & P1 & P2 & P3 \\
\hline K1 & - & $0,028^{*}$ & $0,035^{*}$ & $0,010^{*}$ & $0,001^{*}$ \\
K2 & $0,028^{*}$ & - & $0,001^{*}$ & $0,001^{*}$ & $0,001^{*}$ \\
P1 & $0,035^{*}$ & $0,000^{*}$ & - & 0,568 & 0,081 \\
P2 & $0,010^{*}$ & $0,000^{*}$ & 0,568 & - & 0,223 \\
P3 & $0,001^{*}$ & $0,000^{*}$ & 0,081 & 0,223 & - \\
\hline
\end{tabular}

Tabel 2. diatas, terdapat perbedaan antar kelompok normal (K1) dengan kelompok stres (K2) dengan $p$ value 0,028 , begitu pula antara kelompok normal (K1) dengan kelompok perlakuan (P1) p value 0,035, dengan (P2) $p$ value 0,010 dan dengan (P3) $\mathrm{p}$ value 0,001 menunjukan angka yang signifikan. Selanjutnya terdapat perbedaan yang signifikan antara kelompok stres (K2) dengan seluruh kelompok perlakuan $\mathrm{P} 1$, P2, P3 dengan nilai $p$ value $0,001,0,001$, dan 0,001 berturut-turut.

\section{PEM BAHASAN}

Antioksidan yang paling kritis yang mampu memperbaiki efek tekanan stres oksidatif adalah enzim Superoxide Dismutase (SOD). Struktur representatif tiga dimensi enzim yang merupakan protein ini mengkatalis perubahanperubahan superoksida menjadi hidrogen peroksida dan oksigen. Superoksida adalah suatu radikal bebas yakni molekul yang memiliki elektron tak berpasangan. Oleh karena itu superoksida bersifat sangat 
ISSN 1978-2071 (Print); ISSN 2580-5967 (Online)

Jurnal IImiah Kedokteran Wijaya Kusuma 7(2) : 158-164, September 2018

reaktif dan reaktivitasnya dapat melukai molekul di dalam tubuh. Karena berperan penting, SOD telah menjadi satu cara alternatif untuk meminimalkan kerusakan jaringan akibat radikal bebas. SOD merupakan enzim dengan ramifikasi (percabangan) yang meluas (Nurhayati, dkk., 2011).

Berdasarkan analisis statistik aktivitas SOD pada kelompok kontrol stres dan kelompok perlakuan adalah signifikan ( $p \varangle, 05$ ), namun tidak terdapat perbedaan yang signifikan antara masing-masing perlakuan (P1, P2 dan P3). Kondisi tersebut menunjukkan bahwa aktivitas SOD tidak dipengaruhi oleh waktu pemberian seduhan teh hijau. Meskipun terlihat beda nilai dari ketiga kelompok perlakuan, namun nilai yang didapatkan tidak menunjukkan perbedaan yang bermakna. Hal ini menjelaskan bahwa SOD mungkin saja dipengaruhi oleh dosis seduhan teh hijau yang digunakan, jadi teh yang digunakan untuk menurunkan stres oksidatif tergantung oleh dosis dependen untuk meningkatkan aktivitas SOD, sehingga mungkin perlu digunakan dosis yang lebih tinggi untuk mendapatkan beda yang signifikan pada kelompok perlakuan pada penelitian selanjutnya. Antioksidan dapat dijadikan sebagai terapi dalam mengurangi stres oksidatif. Antioksidan yang berasal dari luar (eksogen) sebagai bahan alami sangat diperlukan dalam membantu aktivitas antioksidan dari dalam (endogen) dalam menangkal radikal bebas penyebab stres oksidatif. Teh hijau dengan kandungan bahan aktif yang bekerja menghambat radikal bebas diharapkan dapat mengurangi risiko akibat dari stres oksidatif.

Teh hijau merupakan bahan baku minuman penyegar yang dipercaya dapat mencegah, mengobati dan menghilangkan gejala penyakit dan telah digunakan selama beribu-ribu tahun. Penelitian tentang manfaat menyehatkan dari teh hijau telah banyak dilakukan. Senyawa kimia dalam teh yang paling besar perannya dalam membentuk cita rasa dan khasiat istimewa adalah polyphenols (Rohdiana, 2009). Polyphenols diakui memiliki aktivitas sebagai antioksidan yang sangat kuat (Yifan, 2014). Kemampuannya menangkap radikal bebas 100 kali lebih efektif dari vitamin C dan 25 kali lebih efektif daripada vitamin E (Hagermae, 2002).

Berdasarkan hasil yang didapatkan, dinyatakan bahwa terdapat perbedaan yang signifikan antara kelompok kontrol normal (K1) dan kelompok kontrol stres (K2) dengan ketiga kelompok perlakuan (P1, P2 dan P3) yang menyebabkan SOD semakin meningkat setelah pemberian teh hijau. SOD terkait dengan sintesis protein. Stres psikologis menimbulkan tekanan 
Pengaruh Pemberian Seduhan Teh Hijau (Camellia Sinensis) Terhadap Aktivitas Superoksida... Ma'rifat Istiqa Mukty, Bambang Wirjatmadi, Bambang Purwanto

pada sintesis protein SOD sehingga menyebabkan SOD menjadi lebih rendah. Hal tersebut dapat dibuktikan dengan penurunan aktivitas SOD akibat hewan coba penelitian yang di papar stres psikologis (K2). Stres psikologis tersebut, sampai menyebabkan sintesis antioksidan endogen mengalami penurunan.

Saat SOD kembali meningkat pada kelompok P1, P2 dan P3 setelah pemberian seduhan teh hijau, hal ini didukung oleh penelitian sebelumnya yang dijelaskan bahwa aktivitas antioksidan dari teh hijau memiliki struktur fenolik yang unik, yang dapat menyumbangkan elektron atau proton ke radikal bebas dan menunjukkan resonansi elektron delokalisasi. Penelitian tersebut menunjukkan efek teh hijau dikaitkan dengan peningkatan regulasi gen untuk SOD dan katalase. Pada tikus, catechin yang berasal dari polyphenols dapat melindungi sel-sel epidermal terhadap perubahan SOD dan katalase yang disebabkan oleh kerusakan radiasi. Dalam sistem lain, teh hijau juga bisa mengaktifkan ekspresi enzim antioksidan lainnya (YukM an Li, 2007).

Stres psikologis dari protokol yang digunakan secara bermakna menyebabkan SOD menurun. Saat diberikan teh hijau, SOD kembali meningkat. Diketahui bahwa SOD merupakan antioksidan endogen dimana saat aktivitas SOD meningkat, maka tubuh akan diproteksi lebih kuat dari adanya paparan radikal bebas untuk aktivitas berikutnya. Melalui hasil penelitian ini, dapat diaplikasikan oleh aktivitas/pekerjaan yang membutuhkan SOD lebih tinggi sebagai proteksi terhadap stress oksidatif (misalnya; Security, shift malam, dan kondisi atau pekerjaan yang mengharuskan seseorang untuk begadang).

Saat kondisi diatas tersebut berlangsung, maka akutnya aktivitas SOD akan mengalami penurunan. Namun, saat diberikan teh hijau, SOD mengalami peningkatan pada jam ke-1 dan jam ke-6, kemudian pada jam ke-24 lebih meningkat lagi. Artinya, seseorang yang berada dalam kondisi/pekerjaan tersebut, saat mengkonsumsi teh hijau maka akan siap untuk beraktivitas hingga 24 jam berikutnya karena proteksi dari SOD yang semakin tinggi pada jam ke 24. Dalam penelitian ini dapat dijelaskan bahwa aktivitas SOD dapat bertahan hingga 24 jam ke depan setelah mengkonsumsi seduhan teh hijau.

Semua nilai kelompok perlakuan (P1, P2 dan P3) mendapatkan hasil yang tidak jauh berbeda (tidak signifikan). Hal ini menjelaskan bahwa SOD sangat dipengaruhi oleh dosis seduhan teh hijau yang digunakan, jadi teh yang digunakan untuk menurunkan stres oksidatif 
ISSN 1978-2071 (Print); ISSN 2580-5967 (Online)

Jurnal IImiah Kedokteran Wijaya Kusuma 7(2) : 158-164, September 2018

tergantung oleh dosis dependen untuk

menurunkan aktivitas SOD, sehingga

mungkin perlu digunakan dosis yang lebih

tinggi untuk mendapatkan beda yang

signifikan pada kelompok perlakuan pada

penelitian selanjutnya.

\section{KESIM PULAN}

Dosis tunggal seduhan teh hijau pada hewan coba yang mengalami stres oksidatif terbukti dapat menetralisir stres oksidatif pada jam ke-1 setelah pemberian teh hijau dan aktivitas antioksidannya masih dapat bertahan sampai 24 jam.

\section{DAFTAR PUSTAKA}

Anjarsari IRD, 2016. Katekin Teh Indonesia: Prospek dan Manfaatnya. Jurnal Kulitivasi. Universitas Padjadjaran Fakultas Agrikultur. Volume 15(2): 99-106

Hagermae AE, 2002. Tannin Chemistry, http://www.users.muohio.edu/h agermae/tannin. pdf, diakses tanggal 10 Juli 2018.
Maramis WF, 2009. Catatan IImu Kedokteran Jiwa. Airlangga University Press, Surabaya. p: 6369

Rohdiana D, 2009. Teh Ini Menyehatkan, Telaah IImiah Populer. Cetakan Pertama. Alfabeta, Bandung

Shabri dan Rohdiana, 2016. Optimasi dan Karakterisasi Ekstrak Polifenol Teh Hijau dari Berbagai Pelarut. Pusat Penelitian Teh dan Kina Gambung

Nurhayati S, Kisnanto T, dan Syaifudin M, 2011. Superoksida Dismutase (SOD): Apa dan Bagaimana Peranannya Dalam Radioterapi. Iptek ilmiah Populer, 13 (2): 67-74

Yi-fan F and Jia-shun G, 2014. Study on in Vitro Antioxidant Activity of Water Extract and Anthocianin from Z-Juan Sun-dried Green Tea. Proceeding of The International Tea Symposium 2014. November 10-13. China: Hangzhou

Li YM, Chan HY, Huang Y, and Chen ZY, 2007. Green tea Catechins Upregulate Superoxide Dismutase and Catalase In Fruit Flies. Nutrition Food Research. 51(5): 546-54 